\title{
急性腎不全を合併したA群連鎖球菌性 原発性腹膜焱の1例
}

小林 正直 冨士原 彰 秋元 寛 森田 大 大石 泰男

原発性腹膜炎とは消化管穿孔などの原因が見いだ されない腹膜炎と定義され，比較的まれな疾患であ る。このうち起炎菌がA群溶血性連鎖球菌（以下， A群連鎖球菌), Streptococcus pyogenes (S.pyogenes) である原発性腹膜炎はきわめてまれで，欧米で10例 が報告されているに過ぎず1-8)，本邦での報告はな い。本菌は猩紅熱，リウマチ熱，急性系球体腎炎の 起炎菌として知られてきたが，近年，ショックや多 臓器障害, 軟部組織壊死, 皮膚疹を呈する劇症型A 群連鎖球菌感染症（toxic shock like syndrome；TSLS） の起炎菌として注目されている ${ }^{9-11)}$ 。

われわれは急性腎不全を伴ったA群連鎖球菌によ る原発性腹膜炎の1例を経験したので, 文献的考察 を加え報告する。

\section{症例}

患 者：35歳の女性，主婦

主 訴: 下腹部痛, 発熱

既往歴：貧血を指摘されていたが，未加療

家族歴：特記事項なし

現病歴: 生来健康であった。当センター搬入の約 1か月前より咽頭痛があったが放置していた。搬入 の前々日に咽頭痛が強くなり, 嚥下が困難になった。 搬入前日より下腹部痛が出現し, 徐々に増強したた

Primary group A Streptococcal peritonitis complicated by acute renal failure

キーワード：原発性腹膜炎, 急性腎不全, A群連鎖球菌 大阪府三島救命救急センタ-

著者連絡先：干569-1124 高柣市南芥川町11-1

原稿受理日：1999年5月24日（99-031）
め近医を受診した。体温は $40.3^{\circ} \mathrm{C} て ゙ 下$ 痢・嘔気・嘔 吐を伴っていたため同医に入院した。補液と抗生剂 sulbactam/cefoperazone（SBT/CPZ）の投与を受けた が, そ尿となり急性腎不全と診断され，腹痛発症から 22時間後に当センターに転送された。なお，最終月経 は搬入の7日前より通常通りにみられ，生理用のタン ポンを使用していたが，異常帯下はなかった。

現 症：意識は清明で, 血圧 $92 / 50 \mathrm{mmHg}$ ，心拍 数 $95 / \mathrm{min}$ 整, 呼吸数 $18 / \mathrm{min}$, 腋窩体温 $36.3^{\circ} \mathrm{C}$, 無尿 であった。眼瞼結膜は貧血状で，表在リンパ節の腫 大はなく，咽頭後壁に発赤，びらんを認めた。項部 硬直はなく，肺野，心音に異常を認めなかった。腹 部全体, とくに下腹部に疼痛を訴え, 軽度の圧痛, 筋性防御, 反跳痛を認めた。腹部超音波検査にて両 側横隔膜下とダグラス窩に腹水を認め，ダグラス窩 の底にはdebris賍留を認めた。腹腔穿刺にて混濁腹 水と無臭性の乳白色粘稠膿汁を吸引した。これを細 菌培養検査 (一般細菌, 結核菌) に提出するととも に，グラム染色を行ったところ，グラム陽性球菌を 認めた。腹部CT検査を行ったが, 腹膜炎の結果と 思われる浮腫状の麻瘏性腸管を認める以外に情報は なかった。

血液・尿検査所見：白血球増多と著明な核の左方 移動を認めた。軽度貧血を認めたが血小板の低下は なかった。止血凝固検查ではプロトロンビン活性の 軽度低下，フィブリノーゲン，FDPの増加を認めた。 血液生化学検査ではBUN, Creの上昇, 低アルブミ ン血症，LDH，CPKの上昇を認め, CRPは高值を呈 していた。動脈血ガス分析は呼吸性に代償された代 謝性アシドーシスの所見であった。検尿・尿沈渣で 
Table 1. Laboratory data on hospital admission.

\begin{tabular}{|c|c|c|c|c|c|}
\hline \multicolumn{2}{|l|}{ Hematology } & $\mathrm{HCO}_{3}^{-}$ & $17.0 \mathrm{mmol} / 1$ & \multicolumn{2}{|l|}{ Urinalysis } \\
\hline WBC & $14,300 / \mathrm{mm}^{3}$ & $\mathrm{BE}$ & $-6.2 \mathrm{mmol} / 1$ & $\mathrm{pH}$ & 5.5 \\
\hline Myl & $10.5 \%$ & \multicolumn{2}{|l|}{ Blood chemistry } & protein & $3+$ \\
\hline Met & $9.5 \%$ & Glu. & $109 \mathrm{mg} / \mathrm{dl}$ & sugar & - \\
\hline St & $63.5 \%$ & BUN & $106 \mathrm{mg} / \mathrm{dl}$ & keton body & - \\
\hline Seg & $18.5 \%$ & Cre & $7.5 \mathrm{mg} / \mathrm{dl}$ & occult blood & $3+$ \\
\hline Eo & $0 \%$ & UA & $12.4 \mathrm{mg} / \mathrm{dl}$ & $\mathrm{RBC}$ & $5 \sim 9 / 1 \mathrm{HPF}$ \\
\hline Ly & $7.0 \%$ & $\mathrm{Na}$ & $138 \mathrm{mmol} / 1$ & WBC & $1 \sim 4 / 1 \mathrm{HPF}$ \\
\hline $\mathrm{RBC}$ & $438 \times 10^{4} / \mathrm{mm}^{3}$ & $\mathrm{~K}$ & $4.1 \mathrm{mmol} / 1$ & transitional ep. & $1 \sim 4 / 1 \mathrm{HPF}$ \\
\hline $\mathrm{Hb}$ & $9.3 \mathrm{~g} / \mathrm{dl}$ & $\mathrm{Cl}$ & $106 \mathrm{mmol} / 1$ & tubular ep. & $1 \sim 4 / 1 \mathrm{HPF}$ \\
\hline $\mathrm{Ht}$ & $30.3 \%$ & $\mathrm{Ca}$ & $8.0 \mathrm{mg} / \mathrm{dl}$ & granular cast & $1 \sim 4 / 1 \mathrm{HPF}$ \\
\hline Plt & $24.5 \times 10^{4} / \mathrm{mm}^{3}$ & $\mathrm{TP}$ & $6.5 \mathrm{~g} / \mathrm{dl}$ & epithelial cast & $1 \sim 4 / 1 \mathrm{HPF}$ \\
\hline \multicolumn{2}{|c|}{ Hematostatic test } & Alb & $2.3 \mathrm{~g} / \mathrm{dl}$ & \multicolumn{2}{|l|}{ Urinary chemistry } \\
\hline PT & $59 \%$ & T-Bil & $0.6 \mathrm{mg} / \mathrm{dl}$ & U-UN & $174 \mathrm{mg} / \mathrm{dl}$ \\
\hline fibrinogen & $648 \mathrm{mg} / \mathrm{dl}$ & AST & $23 \mathrm{U} / 1$ & $\mathrm{U}-\mathrm{Cr}$ & $616 \mathrm{mg} / \mathrm{dl}$ \\
\hline AT-III & $83 \%$ & ALT & $8 \mathrm{U} / 1$ & $\mathrm{U}-\mathrm{Na}$ & $15 \mathrm{mmo} / 1$ \\
\hline FDP & $23 \mu \mathrm{g} / \mathrm{ml}$ & LDH & $248 \mathrm{U} / 1$ & $\mathrm{U}-\mathrm{K}$ & $53 \mathrm{mmol} / 1$ \\
\hline Arterial bloo & & CPK & $413 \mathrm{U} / \mathrm{ml}$ & FENa & 0.13 \\
\hline $\mathrm{pH}$ & 7.403 & $\mathrm{ChE}$ & $6.2 \mathrm{U} / \mathrm{ml}$ & $\mathrm{U}-\mathrm{Cr} / \mathrm{S}-\mathrm{Cr}$ & 82.1 \\
\hline $\mathrm{PaCO}_{2}$ & $27.3 \mathrm{mmHg}$ & Chol. & $100 \mathrm{mg} / \mathrm{dl}$ & U-UN/BUN & 1.64 \\
\hline $\mathrm{PaO}_{2}$ & $109.3 \mathrm{mmHg}$ & CRP & $27.1 \mathrm{mg} / \mathrm{dl}$ & renal failure index & 0.18 \\
\hline
\end{tabular}

は潜血，蛋白，尿細管上皮，円柱を認め，腎性腎不 全の所見であったが，Na排泄は保たれており，腎 前性腎不全の要素もみられた（Table 1）。

膿性腹水にグラム陽性球菌を認めたこと, 消化管 穿孔による腹膜炎にしては自覚症状，腹部所見が軽 微なことより，骨盤腹膜炎の汎発化，または原発性 腹膜炎を疑った。腹腔内精査, 腹腔洗浄を目的とし た試験開腹を行うこととした。

手術所見：臍を中心とした正中切開にて開腹し た。腹腔内全域に膿性腹水を約 $500 \mathrm{ml}$ 認めた。小腸 全域に膿苔が付着し, 漿膜面には発赤を認め, 浮腫 状であったが, 腹膜炎の原因となるものはなかった。 腹膜の発赤はダグラス窩で最も強かった。卵巣は両 側正常で，卵管采は両側浮腫状であったが明らかな 化膿性の変化はなかった。腹腔を十分に洗浄し，ダ グラス窩にドレナージを置き閉腹した。

術後経過：前医でSBT/CPZがすでに投与されてい たが，感受性を期待できたため，術後抗生剤投与も これを使用した。術前，術中合わせ4時間で4,200ml
の輸液を行い，中心静脈圧が $12 \mathrm{cmH}_{2} \mathrm{O}$ まで上昇した が利尿を得られず, 腎性腎不全と考え持続血液濾過 （CHF）を行った。術後, 経鼻経腸栄養チューブを 自己抜去するなど, 軽度の精神症状を認めたものの 一過性であった。経過中に血小板 $10.1 \times 10^{4} / \mathrm{mm}^{3}$, プロトロンビン活性 50\%，抗トロンビンIII 54\%まで 低下，FDP $28 \mu \mathrm{g} / \mathrm{ml}$ まで上昇したが，以後回復した。 第12病日より利尿が得られ，血液浄化より離脱し， 第21病日に軽快退院した。このときASOは960倍 （TIA法，基準値 $\leq 160$ ）,ASKは10,240倍（PA法，基 準值 $\leq 1,280$ ）と上昇，血清補体価は $16 \mathrm{U} / \mathrm{ml}$ （TIA法, 基準值 30～50）， $\mathrm{C}_{3}$ は $11 \mathrm{mg} / \mathrm{dl}$ （TIA法，基準值59～ 120）と低下しており，以後正常に向かった。

後日判明した検査結果 : 腹腔内膿汁より A 群連鎖 球菌 (S.pyogenes), 血清型 $\mathrm{T} 1$ 型 (凝集反応), $\mathrm{M} 1$ 型 (沈降反応)，連鎖球菌発熱性外毒素（Streptococcal pyrogenic exotoxin；SPE） A+B型（PCR法）が検出 された。進入門戸の検索として血液, 咽頭ぬぐい液, 腟内分泌液の細菌培養検査を行ったが，すでに感受 
Table 2. Case review of primary group A Streptococcal peritonitis.

\begin{tabular}{|c|c|c|c|c|c|c|c|}
\hline Author & Age/Sex & $\begin{array}{l}\text { Underlying } \\
\text { disease }\end{array}$ & $\begin{array}{l}\text { Preceded } \\
\text { upper } \\
\text { respiratory } \\
\text { infection }\end{array}$ & $\begin{array}{l}\text { Blood } \\
\text { culture }\end{array}$ & Shock & Organ dysfunction & $\begin{array}{c}\text { Serotype, } \\
\text { exotoxin, } \\
\text { others }\end{array}$ \\
\hline Golden ${ }^{1)}$ & $31 / \mathrm{F}$ & - & + & $\mathrm{NM}^{*}$ & + & - & \\
\hline Khoury ${ }^{2)}$ & $27 / \mathrm{F}$ & anorexia nervosa & + & $\mathrm{NM}^{*}$ & - & kidney, liver & \\
\hline Bibler ${ }^{3)}$ & $62 / \mathrm{F}$ & hyperthyroidism & - & + & - & - & \\
\hline Gribbin $^{4)}$ & $44 / M$ & - & + & + & - & - & \\
\hline Casadevall $^{\text {s) }}$ & $87 / F$ & - & - & + & + & kidney, liver & \\
\hline Casadevall $^{5)}$ & $42 / \mathrm{F}$ & diabetes mellitus & - & + & + & kidney, liver & \\
\hline Christen $^{6)}$ & $50 / \mathrm{F}$ & - & - & + & + & kidney, CNS** & M28, $\operatorname{TSLS}(+)$ \\
\hline Christen $^{6)}$ & $58 / \mathrm{F}$ & rheumatoid arthritis & - & + & + & kidney, DIC*** & $\operatorname{TSLS}(+)$ \\
\hline Brase $^{7)}$ & $34 / F$ & - & $(+)$ & + & - & - & \\
\hline Graham $^{8)}$ & $39 / \mathrm{F}$ & - & + & - & - & - & T3, M3, R3 \\
\hline our case & $35 / F$ & - & + & - & - & kidney, (DIC) & $\mathrm{T} 1, \mathrm{M} 1, \mathrm{SPE} / \mathrm{A}+\mathrm{B}$ \\
\hline
\end{tabular}

$* \mathrm{NM}=$ not mentioned $; * * \mathrm{CNS}=$ central nervous system $; * * * \mathrm{DIC}=$ disseminated intravascular coagulation

性のあるSBT/CPZが投与されていたためか，本菌は 検出されず証明には至らなかった。患者は生理用夕 ンポンを使用していたことから進入門戸として経堗 性上行感染も考慮に入れるべきであるが，先行する 咽頭炎が存在したこと, 子宮付属器炎の所見がなか ったことから, 咽頭から血中, 腹腔へと感染が波及 した可能性が高いと推定した。搬入時のインターロ イキン6（IL-6）は3,910pg/ml（CLEIA法，基準值＜ 4）と著明な高サイトカイン血症を認め, トロンビ ンアンチトロンビン複合体（TAT） 60 $\mathrm{ng} / \mathrm{ml}$ 以上 （EIA法，基準值＜3），Dダイマー 5,652ng/ml（基準 值 $<150)$, 組織プラスミノーゲンアクティベータ・ プラスミノーゲンアクティベータインヒビター 1 複 合体（tPAI·C） 142ng/ml（LPIA法，基準值 $<50 ）$, トロンボモジュリン 8.1FU/ml（EIA法，基準值＜4.5） と高值を示し，血管内皮細胞障害が示唆された。

\section{考察}

原発性腹膜炎は小児ネフローゼ，成人肝硬変にみ られることが多く, 感染経路には血行性, リンパ行 性, 腸管からの壁を介する移行, 胵からの上行感染 があり ${ }^{5)}$, 起炎菌は65～75\%が腸管由来細菌，11〜 23\%が肺炎球菌とされている ${ }^{4}$ 。一方，A群連鎖球 菌はヒ卜感染症の一般的な起炎菌であるが，腸管常
在菌ではなく, 腸管感染源, 腹腔感染源となること はまれで5), $\mathrm{A}$ 群連鎖球菌による原発性腹膜炎はわ れわれが検索したかぎり10例しか報告がなかった。 これらの報告例に自験例を加えた11例について臨床 像を中心に検討を加えた（Table 2)。年齢は27歳か ら87歳, 平均46歳, 中央值42歳と比較的若い年代に 多かった。性別は男性1例, 女性10例と圧倒的に女 性に多く，4例に基礎疾患があった。

症状・所見では腹痛, 発熱が全例にみられ, 嘔吐 が7例, 下痢, 麻痺性イレウスが5例にみられた。自 験例を含む5例に先行上気道感染があり，これらの 腹腔への感染経路は血行性と考えられている ${ }^{2,7)}$ 。経 腔性上行感染と考えられる例は1例のみで ${ }^{2)}$, 残りは 記載なく不明であった。なお，血液培養では7例に 陽性所見が得られた。病態ではショック例が5例， 臓器障害例が6例と多くみられたが, TSLS と明記さ れたものは2例しかなく, 死亡例はなかった。適切 な抗生剤の投与を行えば, A群連鎖球菌性原発性腹 膜炎の予後は悪いものではないと考えられる。

次に自験例における腎不全の発生機序につき考察 を加える。ひとつには溶連菌感染後急性系球体腎炎 poststreptococcal acute glomerulo-nephritis (PSAGN) が考えられるが, PSAGNとするには咽頭痛の急性 増悪とともに発熱, 腹痛, 腎不全がいっきに出現し 
ていた点，高血圧や浮腫を欠く点など典型的とはい えない部分がある。むしろ, 播種性血管内凝固症候 群（DIC）の診断基準を満たすほどではなかったが, 止血凝固障害の存在と, 血管内皮細胞障害マーカー の増加があったことから敗血症による腎不全と考え る方が妥当であろう。A群連鎖球菌による敗血症性 臓器障害となるとTSLS ${ }^{9-11)}$ を連想するが, 自験例 にはショック，軟部組織壊死はなく, TSLSの診断 基準9をを満たさなかった。しかし，自験例はTSLS 症例に関連，類似する部分もみられたため，この点 について述べる。

TSLSは四肢の筋痛, 発熱, 血圧低下が初発症状 できわめて急激に病状が進行し, 発病から数時間以 内にショック, 成人呼吸窮迫症候群 (ARDS), 急 性腎不全，DICに陥り，死亡率は24\%と高い9-11)。 TSLSにおいてA群連鎖球菌感染が重症化する機序と してSPEの関与が指摘されている11,12)。SPEはスーパ 一抗原として非特異的にT細胞を活性させ，その結 果，無秩序に分泌されたサイトカインが多彩な病態 を呈する ${ }^{11,12)}$ 。SPEは分子量によりA，B，C型とこ れらに属さないD型に分類され，アルファベット順

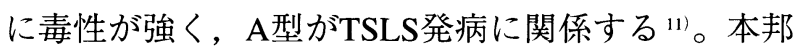
のTSLS症例から検出されたSPEはB+C型, $\mathrm{A}+\mathrm{B}$ 型 が過半数を占める〔(Infectious Agents Surveillance Report ; IASR）の情報, http://idsc.nih.go.jp/iasr/indexj.html]。自験例のSPEはA+B型であり, TSLSで検 出される頻度の高いものと一致しており, TSLS症 例との関連性が示唆される。同じくIASRの情報で, 本邦のTSLSから分離されたA群連鎖球菌の血清型 （T抗原型）はT3型，T1型，T28型，T12型の順に多 い。自験例の血清型はT1型であり，この点からみて もTSLS症例との類似性が示唆される。

以上の文献的考察と A+B型SPEの検出, IL-6の著 増を合わせて自験例の病態を考えると，SPEがサイ トカイン・ネットワークを過剩に活性化させ血管内 皮細胞を障害し, 止血凝固障害, 腎不全などの臓器 障害を来したものと推定される。A群連鎖球菌感染 症にはTSLSを呈するものから呈さないものまで病
態に幅があるが，自験例はその中間に位置するもの と考えられる。すなわち自験例にはTSLSが起こる 素地はあったが，早期の抗生剂投与などにより，そ の外毒素量は生体にとって耐えうる量であったもの と推測できる。

\section{まとめ}

急性腎不全を合併したA群連鎖球菌による原発性 腹膜炎の 1 症例を経験した。発熱性外毒素型を検索 し，高サイトカイン血症，血管内皮細胞障害を中心 とした病態について興味深い知見を得たので，文献 的考察を加え報告した。

謝辞：終わりに, 細菌の血清型判定および発熱性毒素 型検査に御尽力いただいた大阪府立公衆衛生研究所微生 物課の勝川千尋先生に謝意を表します。

\section{文献}

1) Golden GT, Stevenson TR, Ritchie WP Jr : Primary peritonitis in adults. South Med J $1975 ; 68: 413-4$.

2) Khoury GA, Wall RA : Streptococcal peritonitis associated with the cathartic colon. Br J Surg $1982 ; 69: 327$.

3) Bibler MR, Rouan GW : Cryptogenic group A Streptococcal bacteremia : experience at an urban general hospital and review of the literature. Rev Infect Dis $1986 ; 8: 941-51$.

4) Gribbin JC, Cox CJ : Spontaneous bacterial peritonitis in a healthy adult male. Aust N Z J Surg $1990 ; 60: 723-5$.

5) Casadevall A, Pirofski LA, Catalano MT : Primary group A Streptococcal peritonitis in adults. Am J Med 1990 ; $88(5 \mathrm{~N}): 63 \mathrm{~N}-64 \mathrm{~N}$.

6) Christen RD, Moser R, Schlup P, et al : Fulminant group A Streptococcal infections. Report of two cases. Klin Wochenschr $1990 ; 68: 427-30$.

7) Brase R, Kuckelt W, Manhold C, et al : Spontaneous bacterial peritonitis without ascites. Anästhesiol Intensiv Med Notfallmed Schmerzther $1992 ; 27$ : 325-7.

8) Graham JC, Moss PJ, Mckendrick MW : Primary group A Streptococcal peritonitis. Scand J Infect Dis 1995 ; $27: 171-2$.

9) Defining the group A streptococcal toxic shock syndrome. Rationale and consensus definition. The Working Group on Severe Streptococcal Infections. JAMA $1993 ; 269$ : 390-1.

10) Wood TF, Potter MA, Jonasson O : Streptococcal toxic shock-like syndrome. The importance of surgical interven- 
tion. Ann Surg $1993 ; 217: 109-14$.

11）清水可方：劇症型A群溶レン菌感染症（toxic shock like syndrome）に関する最近の知見. メディヤサークル $1994 ; 39: 1-7$.
12）内山竹彦：MHCクラスII分子に結合してT細胞を活性 化する細菌外毒素一外毒素性異常反応の機序一。臨床 免 $1990 ; 22 ： 1544-52$.

\section{ABSTRACT \\ Primary Group A Streptococcal Peritonitis Complicated by Acute Renal Failure \\ Masanao Kobayashi, Akira Fujiwara, Hiroshi Akimoto \\ Hiroshi Morita and Yasuo Ohishi \\ Osaka Mishima Critical Care Medical Center}

We report a case of primary group A Streptococcal peritonitis complicated by acute renal failure in a previously healthy 35-year-old woman. The patient complained of a 30-hour history of fever and lower abdominal pain. She was anuric,but not in shock on hospital admission. Her abdomen was slightly tender and rebound tenderness and muscle guarding were observed. Laboratory examination revealed leukocytosis (WBC $14,300 / \mathrm{mm}^{3}$ ) with a shift to the left, and azotemia (BUN $106 \mathrm{mg} / \mathrm{dl}$, Cre $7.5 \mathrm{mg} / \mathrm{dl}$ ). A clinical diagnosis primary peritonitis was suggested, and laparotomy was performed with initiation of fluid resuscitation. At operation, purulent ascites was observed, but no gastrointestinal tract perforation could be identified. Abdominal lavage and drainage were conducted. Postoperatively, hemofiltration was carried out for acute renal failure, and urination returned on the 11th postoperative day. On microbiological investigation, group A Streptoccus (S.pyogenes)(serotype T1/M1, Streptococcal pyogenic exotoxin : SPE/A +B) was detected in the intraperitoneal pus. Serum analysis revealed interleukin-6 level of $3,910 \mathrm{pg} / \mathrm{ml}$, thrombomodulin $8.1 \mathrm{FU} / \mathrm{ml}$, and tissue plasminogen activator plasminogen activator inhibitor- 1 complex (t-PAI - C) $124 \mathrm{ng} / \mathrm{ml}$. Discussion of the relevance of these findings to toxic shocklike syndrome (TSLS) is included.

(JJAAM $2000 ; 11: 118-22$ )

Key Words : primary peritonitis, acute renal failure, group A Streptococcus

Received for publication on May 24, 1999 (99-031) 